\title{
Is Dependency Always Bad? Costa Rica-a Case for Dependent Development
}

\section{Ennio Rodríguez'}

\section{Introduction}

Dependency analysis in its critique of import substituting industrialisation implicitly assumes an alternative social order. Dependency may be defined in terms of political alliances of domination, or of characteristics of the industrial structure (absence of a capital goods sector), but these and other formulations share an ideological rejection of the status quo. dependency being at the root of all maladies. Nevertheless, specification of alternative development paths is rare and in most cases the implicit ideals are either an autarkic socialism or the political project of a historically absent national bourgeoisie.

This article attempts not to fall into this trap. Indeed, is our contention that a case for dependent development can be made for Costa Rica from a perspective which underlines the costs and benefits to labour which such a strategy entails. Analytically, we arrive at this conclusion after considering the available historical alternatives in terms of their effects on the majority of the population. In this judgement secure employment opportunities and non-authoritarian political regimes are considered central, although in a different set of circumstances political control over the investment function would appear as a paramount principle of social organisation which would benefit labour. We argue that such conditions are not present in Costa Rica, and therefore that an attempt at socialist transformation, even assuming its political feasibility, might result in higher costs than those entailed by integration to the capitalist camp.

Present-day Costa Ricans enjoy surprisingly high living standards which have been achieved in spite of the fact that the economy is integrated into the global capitalist system as a non-industrial society. Measured in terms of health and literacy levels, living standards are only matched by Cuba in the Latin American continent; income per head is the highest in Central America and probably the best distributed. Repression as a means of political control is insignificant by western standards and the army was disbanded in 1950 since it was considered a threat to democratic institutions. With minor interruptions a liberal democratic state has operated for more than a century. Unemployment and underemployment do not rank as serious problems today.

\footnotetext{
The author would like to thank Martin Godfrey for many useful comments.
}

All this suggests, first, that the production structures resulting from internal processes and from the dynamics of integration into a larger system have not only offered employment possibilities to the majority of the population but have also not led to an immediate concentration of economic power in the hands of the few. The social configurations which have corresponded to these productive structures have set the stage for non-authoritarian political developments. Secondly, it suggests the implemented strategies of development have represented the most progressive options available.

\section{Historical Background ${ }^{2}$}

The absence of precious metals, a small and declining Indian population and the strategic/military unimportance of Costa Rica offered no incentives to the Spanish Crown. It was the availability of land which was the major driving force for the Spaniards who migrated to this marginal area of the Empire. Nevertheless, from the beginning of the colony there were social differences between the aristocrats and the commoners among the Spaniards [Stone 1974:107]. The nobility brought riches from Spain and attempted to use the political power they could derive from the Crown to increase their welfare.

Given the absence of an internal market, if the intended productive activities were to generate any surplus they had to be oriented towards foreign markets. This was the case with the cattle raising ranches, the cacao plantations and tobacco. However, in addition, the Spanish colonial structure of domination set up mechanisms of surplus appropriation which suffocated the attempts of the settlers to develop economic activities. In particular, the heavy taxation burden imposed by the colonial authorities and the Church and the strict control on trade through a carefully designed system of grants and monopolies, guaranteed that all surplus generated in the province was appropriated and, moreover, that no competition was offered to economic activities located elsewhere or to trade routes.

Thus, during the colonial period first cacao and then tobacco cultivation failed and towards the end of this period the province was characterised by a stagnant subsistence economy. This campesino economy, as

2 This section is largely based on Rodriguez | $1979 \mid$. 
G. Rodríguez [ 1979] has called it, was notable for an almost complete absence of market relations, wage, slave and serf labour and mechanism of surplus extraction besides the colonial system. With this practically undifferentiated productive structure was associated a unique class configuration consisting of a vast mass of campesinos from whom the colonial system extracted surplus but who were otherwise unrelated to each other.

Independence was granted to the province during the collapse of the Spanish Empire. The Act of Independence was literally delivered in Cartago; it was not the outcome of any liberation struggle. But once it was achieved, a brief civil war took place between the two competing social groups-Liberals and Conservatives. The issues in the armed conflict were the annexation to Mexico and the location of the capital. The Liberals won the military confrontation, but 20 years after Independence the struggle between the two groups still continued. The possibility of falling into an anarchic period (such as other Central American former Spanish provinces underwent for periods lasting up to 50 years) was real.

However, the formation of a new political structure that could foster a progressive development of the productive forces took only a few years (between 1835 and 1842) and there was scarcely any bloodshed in Costa Rica. The colonial structure of domination was dismantled; the development of foreign trade was fostered; governmental intervention was reduced in economic matters; a central authority was legitimised; and national sovereignity was recognised internationally [Rodríguez 1979:37].

Traditionally, the formation of a centralised authority whose legitimacy has permeated the layers of Costa Rican society - has been attributed to the personal characteristics of Carrillo, the president during this period [Cerdas-Cruz 1972]. Without wishing to detract from his capacity to understand his historical mission, we would rather stress that his actions were possible to the extent that some basic historical conditions were present.

A situation of stalemate between the two competing groups in the context of a campesino society meant that the interests of the majority of the population were related to securing access to their small holdings and to the possibility of trade. This permitted Carrillo to elevate himself over the immediate interests of the Conservatives and the Liberals. So, whilst apparently representing the interests of the small proprietors and issuing decrees in their favour, he created the conditions for the development of a dominant class that was to control society along the lines of the Liberal project.
With Carrillo the conditions were laid for the expansion of production based on small property, with a superstructural frame that sanctified the process of concentration of land-ownership that was already occurring. These then were the conditions for a proper development of what was soon to constitute the dominant class - the coffee oligarchy.

A few months prior to Independence the colonial authorities had taken the first of what was to be a long chain of government measures to promote the cultivation of coffee in the farms of what had so far been campesino units [Facio-Brenes 1972]. In 1832 the first coffee beans were exported to Chile for reshipment to Europe. From then onwards the expansion of production was extraordinary. The total crop was around half a million pounds in 1832 and it had increased to nearly 90 million pounds in 1841. Although a process of land concentration eventually undermined the productive structure based on small family units, the seasonal requirements of labour in the production of coffee encouraged a symbiosis between large haciendas and surrounding family plots. Additionally, capital could appropriate surplus in the processing and export of the commodity, avoiding the risks of production.

The development of coffee production encouraged a social division of labour, first, between the producer, the producer-processor and the producer-processorexporter. The profits of the business were unevenly distributed in favour of the exporter at the expense of the small producer, as was access to credit. Secondly, the group of exporters was subdivided into exporters and importers. Finally, the process of land concentration gave rise to another social class, the peon, the dispossessed peasant who from then on was to obtain his subsistence by selling his labour in the market or else was to migrate to the agricultural frontier.

This process of class formation reflected a concentration of political power in the hands of the coffee oligarchy. This class became dominant and controlled the state apparatus, which was used to develop the legal mechanisms of capitalist production and to provide the basic communications infrastructure for production as well as some services and ideological means of control over the whole of society. The absence of authoritarian forms of state of the kind developed in other parts of Latin America can be partially explained by the characteristics of the productive structure and its capacity to cope with the contradictions which the strategy of development entailed. Other explanations should be sought in the nature of class alliances which developed during this period and perhaps in the personal characteristics of the political leaders.

Integration into the global capitalist system made the process of expansion of the economy vulnerable to 
the crises of the core economies of the system and to the fluctuations of the coffee market |Facio-Brenes 1972:49|. However, the escape route from consequent crises of accumulation as well as from any surplus population resulting from the process of land concentration was provided by the colonisation of vast, fertile untilled lands. Migration into such areas was not only spontaneous but also promoted by the state: long lists of land grants and homestead acts were approved by the Congress which authorised and encouraged those who wanted land to take it [Soley-Guell 1946:167|. This possibility of migrating to the subsistence sector not only allowed for a situation of full employment in the capitalist sector but also operated as a constraint on the extent to which it could lower wages to increase profits (thus, it can be argued, also preventing 'unequal exchange' mechanisms from operating).

Another productive activity which developed as a result of the construction of the communications system was the production of bananas. Plantations, developed by US capital towards the end of the nineteenth century, expanded employment possibilities. They absorbed the labour force brought from Jamaica to build railways and the peasants extruded by the capitalism of coffee. Employment was also fostered indirectly, as cities were developed to provide services to the banana workers. Nevertheless, these developments were vulnerable to changes of location by companies, depressing whole areas such as the Atlantic Zone in 1934. Also, and in spite of the characteristic profit repatriation of the multinationals, any costs incurred by the company locally meant that hard currency was available to ease balance of payments difficulties. Thus, the expansion of banana production contributed to alleviating two of the problems of this development strategy, employment and balance of payments effects. However, such activities are highly vulnerable to the crises of the capitalist system.

In terms of class formation the banana plantations created the first important concentration of proletarians and hence opened up the potential for labour organisations. The unions which developed have gained significant advantages for the banana workers and have also had some influence in the historic events of the 1930 s and 1970 s.

Generally, most authors agree that the development of Costa Rica during this period was rather successful. Although in material terms, Costa Rica at Independence in 1821 was the poorest and the most isolated province in the Central American isthmus, indeed in the American continent, it was the first in Central America to have its capital connected by railroad to both the Atlantic and the Pacific Oceans, electricity supplied to the main cities, a good education system and an adequate road network [Stone 1974:99-100].

Nevertheless, the already mentioned vulnerability of the strategy of development brought crisis during the great depression and the second world war. The contraction of economic activity was reflected in unemployment and the first period of social unrest in Costa Rican history. There were strikes of urban artisans and labourers in small industries, such as shoemakers and bakers. The Communist Party was founded in 1931 and in 1934 party leaders directed the first successful strike against the United Fruit Company. Industrialisation was not an alternative to which commercial and export capital could direct its funds, as happened in other Latin American countries. This was not due to the incapacity of the dominant classes but to the breakdown in foreign trade which left virtually no protected internal market and, hence, no investment opportunities.

The remedy for the employment problem was again the colonisation of virgin lands. The government issued two homestead acts, in 1934 and 1939, with the clear intention of tackling the employment problem. Relief also came from the sudden demand for workers from the construction of the Panama Canal.

Politically, the crisis in the process of accumulation was not reflected in a move towards more rigid power structures to safeguard the structure of property relations. This was probably due to the existence of alternative sources of employment, but the nature of the class alliances represented in the state was also important. In contrast to neighbouring countries it was not a purely oligarchic state. The movements of strike and protest were institutionally channelled, so that the liberal form of the state was transformed in order to provide for the demands of the working classes as well as of the coffee interests. In 1933 a minimum wage for agricultural workers was established and in the $1940 \mathrm{~s}$ an advanced system of labour legislation and social security was achieved. In these reforms the participation of the Communist Party and of the Catholic Church was also important.

\section{Import Substituting Industrialisation}

The first post-war decade was a period of unprecedented prosperity for the Central American economies. The expansion of exports allowed an increase in the size of the services sector, especially in commerce and public and private bureaucracies. This period was also characterised by rising health standards and a demographic explosion.

A process of import substitution was under way based on the expansion of global demand and the monetary 
measures of 1950 which had protectionist effects in spite of having been issued for fiscal purposes. Soon after, in 1954, partly as a result of pressure from the new industrial interests and also because of a deliberate decision of the state to promote the development of an entrepreneurial class and an industrial base, a tariff structure was designed to encourage industrial growth, and, finally, the Law of Protection and Industrial Development was issued in 1959.

An attempt at electoral fraud gave rise to a brief armed conflict in 1949. Respect for suffrage was soon re-established, but the constellation of forces in power was shaken. A group of young middle class intellectuals and entrepreneurs, with a social democratic and modernising ideology, entered the political arena to dispute the power of the traditional dominant classes linked to export and import activities. During this period the state underwent another metamorphosis. The degree of interventionism increased with nationalisations of key sectors of the economy such as energy and banks, and the establishment of various institutions to meet the demands of the poor, small producers and the private sector in general.

The expansion of the economy was seriously hampered by a deterioration in the terms of trade during the second post-war decade. The social implications of this were mitigated by an increase in productivity and growth in industry and services, but this new strategy of development had two major flaws. First, it was unable to generate a significant number of industrial jobs in a period in which access to colonisation areas was becoming increasingly difficult and, secondly, it imposed a new strain on the balance of payments. This was partly due to the deterioration in the terms of trade itself, but also, as the process of import substitution advanced, the balance of the import structure shifted from finished goods to industrial inputs. This made it more difficult to restrict the volume of imports, since any such attempt would have affected the level of industrial activity.

In this context the project of the Central American Common Market was seen as a means for promoting industrial development. The initial project was formulated by ECLA and found support among the modernising sectors, industrial and intellectual groups. The effects of the expansion of US transnationals had not been felt in Costa Rica. Probably the smallness of the market and the magnitude of the tariffs meant investment was not justified. But once the liberalisation of trade barriers among the Central American countries was agreed and a highly protectionist wall was set up the situation was drastically changed. ECLA's project was altered to suit the interests of the United States. The principles of reciprocity in the coordination of development plans, in the execution of regional agricultural and industrial policies, in balanced development and in the formation of Central American multinationals were exchanged for the US scheme, which included unrestricted free trade, free functioning of market mechanisms and financial assistance to countries in difficulties as a consequence of their participation in the Common Market [Lizano-Fait 1975:2051. The modified project was acceptable to national industrial capital. The idea of merging with foreign capital and, hence, internationalising the scope of operations was probably seen as attractive. Politically, the presence of international capital with local participation has probably reduced the likelihood of the government imposing controls on capital movements in the future.

Costa Rica entered the Common Market in 1963. Since then impressive rates of industrial growth have undoubtedly been achieved. Industrial production (widely defined), nearly constant for the previous decade, increased from 25 per cent of GDP in 1962 to 29 per cent in 1973. In 1962-75, industrial product increased more than sixfold while population rose by only 37 per cent. The rate of growth of the labour force during the first decade of the Common Market was 3.6 per cent per annum, but industry managed to increase its share of total employment from 22 to 25 per cent. Income does not seem to have been further concentrated as a result of the expansion in industrial activity. Between 1961 and 1971 the 30 per cent of families with the lowest income maintained their share of the national income (around 10 per cent), while the next lowest 60 per cent of families increased their share from 44 to 56 per cent [Cespedes 1973:103]. The increase in industrial exports to Central America was considerable, but the net effect on the balance of payments seems not to have been significantly positive, owing to the effects of importing inputs, profit repatriation and transfer pricing.

Before attempting any overall comment on the performance of this strategy of development, we need to consider two current evaluations of the integrationist project. One thesis is that, as a result of the process of import substitution, the Central American economies have become disarticulated and incapable of selfreliant growth. This description is valid, but what is less so is the assumption that it could have been otherwise [Garnier-Rimolo and Herrero-Acosta 1977:128-135, Molina-Chocano 1974: 42,88-921. A first difficulty with this assumption is that the political requirements for such an alternative strategy can hardly be conceived as likely to materialise in a political unit larger than the nation-state; thus, the case for a self-reliant strategy of development would have to be made for Costa Rica alone. In these 
circumstances, a Chinese-type autarkic disengagement from the capitalist system seems unlikely to be viable. The scarcity of raw materials in Costa Rica and the export-oriented productive structure would probably require a highly repressive regime capable of depressing the living standards of a large proportion of the population for a long period and, even in these conditions, the intended capital goods sector would be severely limited in efficiency by the size of the market. The partial integration into the capitalist camp of a selfreliant Costa Rica could hardly lead to autonomous growth since this seems to be beyond the constraints set by the logic of capital on the room for manoeuvre of small peripheral economies. Also, the destabilising efforts of the imperial powers would probably make it difficult to reproduce, let alone expand, economic activities in the short run. This also raises questions about the nature of the political regime that could withstand such pressures. Integration into a larger socialist bloc (an implausible assumption in any case) would very likely lead to specialisation, in the case of an economy with 25 per cent of the Cuban population, rather than to self-reliant industrial development.

These comments are not intended as a definitive answer - that is a task for history and not for theoretical analysis alone; but to blame capitalism for being unable to achieve autonomous growth in small economies seems a poor ideological justification for socialism. To pose a possibility apparently beyond reach and then react against the prevailing social order for being unable to achieve it seems a weak contribution to social change. Moreover, what emerges from these considerations is that the political and social costs of an attempt to initiate a transition towards socialism for this particular society would seem higher than this author is prepared to support.

An alternative evaluative approach rests on the 'neoclassical' view that the industrial investment achieved by the import substituting strategy should be assessed by analysing the effects on employment of investing the same amount of resources in other sectors of the economy. The difficulty with this proposal is the assumption that the investment opportunities exist in the other sectors, and that private capital is unable to perceive them because of the 'market distortion' introduced by the industrialisation strategy. There seems little empirical basis for this assumption; on the one hand, the meagre possibilities for expansion alongside the traditional export sector were the reason for the import substituting strategy [Castillo 1966:66], whilst on the other, it seems unlikely that Costa Rica could have been a competitive location for the few runaway industries which have been concentrated in new industrial centres. Besides, the disadvantage in terms of location compared with Puerto Rico and the Mexican border, the crucial attraction of a cheap unorganisedrepressed - labour force has not been present in Costa Rica.

Thus, neither the 'self-reliant' nor the 'neo-classical' strategies seem to have been on the historical agenda of Costa Rica. Given a virtual absence of basic mineral resources, her geopolitical location and the more or less satisfactory consequences of integration to most of the two million of her population, participation in the Central American Common Market (although not perfectly managed - particularly in its lack of control over foreign capital) appears the best available alternative in terms of growth, employment, income distribution and political stability.

\section{World Crisis and Internal Reactions}

The import substituting strategy of development had two major weaknesses: first, its vulnerability to fluctuations in the world economy and, secondly, the eventual exhaustion of the investment opportunities arising from the easy stage of import substitution.

Negative effects from these two causes were to coincide towards the middle of the 1970s. Nevertheless, the economic policy that was implemented cushioned the inflationary and recessionary pressures of the 1974-75 world economy in the short term. At the same time the basis of the model of accumulation was somewhat shifted; the political system showed itself capable of responding to the organised demands of the rural unemployed; and, finally, the commodity (mainly coffee) booms of the period, injected dynamism into the economy. Thus, the effects of this recession were successfully met and its symptoms tended to disappear. Balance of payments difficulties were mitigated, the capacity of the economy to grow at fast rates was renewed and unemployment returned to previous levels (below 4 per cent).

Economic policy for this period was not inspired by a monetarist ideology but dealt with inflationary pressures while protecting employment levels and consumption standards of the low income strata. At the centre was an incomes policy which transferred income from the high and middle towards the low income groups; as a result the pattern of demand shifted from imported to locally produced commodities, easing the balance of payments difficulties and avoiding the import of external inflation. Fiscal and monetary policy were geared towards increasing production or at least maintaining its levels. This basic package was successful because inflationary pressures were of an imported-cost-push nature and inflationary behaviour had not spread among workers and consumers [ILO 1979]. 
Sluggishness in private investment, both a result of world recession and uncertainty and the exhaustion of the easy phase of import substitution, was to be compensated by heavy involvement of the state in productive activities. Investment was to be directed to the development of basic industries, profitable only in the long run, and to joint ventures with multinationals, especially in the new field of agro-industry. However, this programme ran into opposition from sectors of private capital fearing competition from the state in productive activities and from middle-income groups which had suffered from the incomes policy. Indeed the attempt to change the basis of the process of accummulation has ground to a virtual halt since the victory in the 1978 election of the Unidad party, backed by the traditionally dominant class and influenced by free trade ideologies. The new government met a situation in which the recessionary and inflationary pressures of the world capitalist system were reasserting themselves.

In response, the government has timidly and inconsistently moved towards a liberalisation of the economy. However, fortunately the 'liberal' proponents lack the political and military power needed to push through a programme of de-industrialisation. Consequently, the external crisis will undoubtedly start to manifest itself internally. So far a situation of excess liquidity in the economy has provided a cushion against recessionary pressures, but inflation is already escalating and foreign reserves are falling dangerously.

This prospect is a matter of concern to intellectuals and political organisations. A glance at Costa Rican newspapers will show that the overall strategy of development is firmly on the agenda of the political discussion. The controversy concerns both the strategy implemented during the previous two decades and possible future courses of action.

Three main positions can be identified in this controversy. The 'liberals' are claiming that there is a need to remove all distortions from the economy in order to 'get factor prices right', the policy conclusion supposedly derived from a neo-classical model. The radicals see the root of the current maladies in capitalism and propose a disengagement from it in a political alliance that would eventually set the basis for a transition towards socialism. Finally, the social democratic position emphasises the need to increase state intervention in economic affairs in order to ensure the dynamism of the accumulation process and the generation of sufficient employment opportunities.
In conclusion, all three ideological and political views share the diagnosis that the strategy of development of the past two decades has exhausted its dynamic capacities and that significant changes are required. Costa Rica is indeed at a crossroads!

note: the more general dependency references are not given here but in the bibliography at the end of this Bulletin.

\section{References}

Castillo, C. M., 1966, Growth and Integration in Central America, Praeger, New York, Washington, London

Cerdas-Cruz, R., 1972, La crisis de la democracia liberal, EDUCA, San José

Cespedes, V. H., 1973, Costa Rica: la distribución del ingreso y el consumo de algunos alimentos, Universidad de Costa Rica, San José

Facio-Brenes, R., 1972, Estudio sobre economía costarricense, Editorial Costa Rica, San José

Garnier-Rimolo, L. and Herrero-Acosta, F.. 1977. 'El desarrollo de la industria en Costa Rica: elementos para su interpretación', Universidad de Costa Rica, unpublished Licenciatura dissertation, San José

International Labour Office, 1979, Investigaciones sobre empleo 16: salarios, precios y empleo en coyuntura de crisis externa, Costa Rica, 1973-1975, ILO/PREALC, Santiago

Lizano-Fait, E., 1975, 'El proceso de integración economica' in Torres-Rivas, E. (ed), Centroamérica Hoy, Siglo veintiuno Editores, SA, Mexico

- 1975, 'Una reflexion acerca de la integración económica centroamericana' in Cambio Social en Costa Rica, Editorial Costa Rica, San José

Molina-Chocano, G., 1974, Integración centroamericana y dominación internacional, EDUCA, San José

Rodríguez, G. M., 1979, 'Economic Development during the Colonial Period and Political Implications after Independence: the Case of Costa Rica (1573-1842)', unpublished MA dissertation, University of Sussex

Soley-Guell, T., 1946, Historia económica y hacendaria de Costa Rica, Editorial Universitaria, San José

Stone, S., 1974, La dinastia de los conquistadores: la crisis del poder en la Costa Rica contemporánea. EDUCA, San José 